\title{
Microbial production of rhamnolipids using sugars as carbon sources
}

\author{
Yun Nian $\operatorname{Tan}^{1,2}$ and Qingxin $\mathrm{Li}^{2 *}$ (1)
}

\begin{abstract}
Rhamnolipids are a class of biosurfactants with effective surface-active properties. The high cost of microbial production of rhamnolipids largely affects their commercial applications. To reduce the production post, research has been carried out in screening more powerful strains, engineering microbes with higher biosurfactant yields and exploring cheaper substrates to reduce the production cost. Extensive refining is required for biosurfactant production using oils and oil-containing wastes, necessitating the use of complex and expensive biosurfactant recovery methods such as extraction with solvents or acid precipitation. As raw materials normally can account for 10-30\% of the overall production cost, sugars have been proven to be an alternative carbon source for microbial production of rhamnolipids due to its lower costs and straightforward processing techniques. Studies have thus been focused on using tropical agroindustrial crop residues as renewable substrates. Herein, we reviewed studies that are using sugar-containing substrates as carbon sources for producing rhamnolipids. We speculate that sugars derived from agricultural wastes rich in cellulose and sugar-containing wastes are potential carbon sources in fermentation while challenges still remain in large scales.
\end{abstract}

Keywords: Rhamnolipids, Cellulose, Waste, Biotransformation, Fermentation

\section{Introduction}

Microorganisms such as yeast, bacteria or fungi can produce biosurfactants-surface-active compounds using different substrates such as oils, glycerol, alkanes, sugars and wastes [1-3]. Biosurfactants are biodegradable, making them an attractive alternative to chemically synthesized surfactants which are normally petroleum-based and environmentally hazardous [2, 4-8]. Biosurfactants produced by microorganisms are classified into five major groups including glycolipids, lipopolysaccharides, lipopeptides, phospholipids and fatty acids [9].

Rhamnolipids, a class of glycolipid biosurfactants, are composed of one or two L-rhamnose molecules linked with one or two $\beta$-hydroxy fatty acids [10-12]. They are used in various fields such as hydrocarbon degradation, microbial enhanced oil recovery, metal remediation,

\footnotetext{
*Correspondence: li_qingxin@ices.a-star.edu.sg

${ }^{2}$ Institute of Chemical and Engineering Sciences, Agency for Science, Technology and Research, 1 Pesek Road, Singapore, Jurong Island 627833, Singapore

Full list of author information is available at the end of the article
}

plant pathogen elimination, bio-pesticides, wound healing and skin treatment therapeutics $[2,8,13]$. Rhamnolipids are predominantly produced by Pseudomonas aeruginosa ( $P$. aeruginosa) while other bacteria such as P. chlororaphis, P. plantarii, P. putida, P. fluorescens and Burkholderia thailandensis E264 also produce rhamnolipids [14-16]. In addition to the screened strains from different environment, fungus and engineered bacteria are able to produce rhamnolipids [17]. Rhamnolipids producing related enzymes can be introduced to bacteria and yeast to create strains which use sugars and other carbon sources for rhamnolipid production [18-25].

High production costs pose as the major obstacle to the widespread usage of biosurfactants [26]. Strategies to make biosurfactants commercially competitive include accessing agro-industrial wastes as cheap feedstock, developing overproducing robust wild-type or engineered strains, optimizing fermentation and downstream processes and combining production of biosurfactants with other biomolecules such as enzymes or bioplastics $[12,27]$. Here we review the latest progress in microbial 
production of rhamnolipids using sugars derived from industrial wastes as the carbon sources.

\section{From sugar to rhamnolipids}

The metabolic pathway of rhamnolipids production in Pseudomonas has been well characterized [28-31]. Glucose can be used for microbial production of rhamnolipids (Fig. 1) as it can be converted into the precursors required for rhamnolipids synthesis. Glucose can be converted into the sugar moiety-deoxythymidine diphosphate (dTDP)-L-rhamnose. The enzymes required for catalysis are present in most bacteria [32]. For the hydrophobic moiety, the precursor-Acetyl coenzyme A (Acyl-CoA) for fatty synthesis can be obtained from glucose [28]. In addition, the unique rhamnosyltransferase
RhlA in Pseudomonas is required for the synthesis of the hydrophobic moieties such as 3-(3-hydroxyalkanoyloxy) alkanoic acid (HAA) [22, 33]. To obtain mono- and dirhamnolipids, RhlB and RhlC are indispensable for the catalysis [30, 34] (Fig. 1). In addition to glucose, other sugars such as lactose can serve as carbon sources for biosurfactant production. It has been noted that rhamnolipids synthesis is a complicated process and regulated by other pathways [35]. Supplying glucose in the medium can not guarantee rhamnolipids production. Fermentation control is still required as rhamnolipids production in an inducible process. Bacterial quorum sensing (QS) system is one of the regulators that affect rhamnolipids production, which requires signal molecules and modulators [12, 29, 35-37]. The QS system is a complicate

a
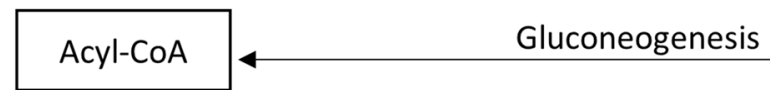

Glucose

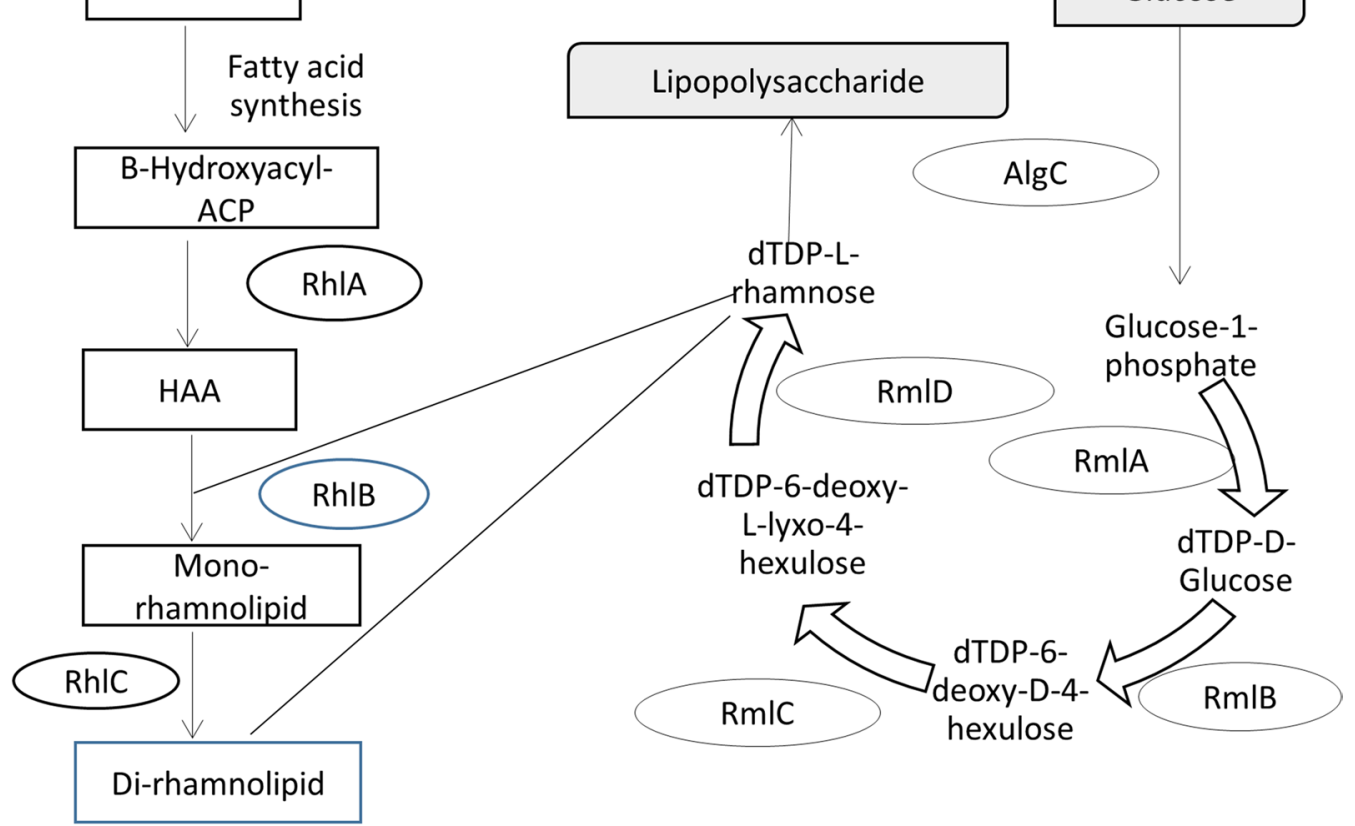

b

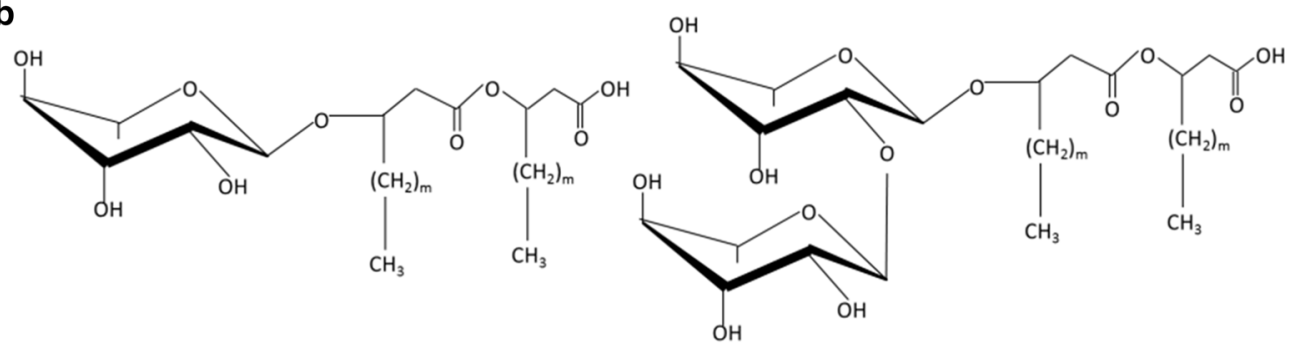

Fig. 1 Rhamnolipids synthesis from glucose. a Glucose can be converted into dTDP-L-rhamnose which serves as the sugar moiety and Acyl-CoA which can be produced from glucose and converted into the hydrophobic moiety. Some important enzymes such as glucose-1-phosphate thymidyltransferase (RmIA), dTDP-D-glucose-4,6-dehydratase (RmIB), dTDP-4-keto-6-deoxy-D-glucose-3,5-epimerase (RmIC), and dTDP-4-keto-L-rhamnose reductase (RmID) [149] are shown. $\mathbf{b}$ Chemical structures of mono- and di-rhamnolipid 
system and regulators that are affecting rhamnolipids production have been reviewed in several literatures [38-40].

\section{Microbial production of rhamnolipids using sugar-containing substrates}

Carbon sources including sugars, glycerol, n-alkanes, oils and polycyclic aromatic hydrocarbons have been used for microbial production of rhamnolipids with various yields [41-45]. Currently, the highest rhamnolipids yield is obtained from oil-type carbon sources as they can be easily degraded through the $\beta$-oxidation pathway [46]. Recently, interest has arisen in using sugar-containing media as potential substrates for rhamnolipids production despite the lower yields [12]. The cost of sugar-containing wastes is lower than that of oilor glycerol-containing wastes [47]. In addition, rhamnolipids are strong emulsifiers and extensive organic solvent extraction is required for product separation and purification from oily substrates [36, 48]. Sugar-containing substrates are shown to serve as a carbon source for rhamnolipids production (Fig. 2, Table 1). The components of these substrate are complicated while sugars are the major component (Table 1). It has been noted that other residue components such as proteins, amino acids or lipids might be important for the rhamnolipids production (Table 1).

\section{Molasses}

Molasses is a byproduct rich in sugars. Soy molasses are generated during soybean processing and composed of carbohydrates, minerals, fats, lipids and others. Soy molasses contain mixture of sugars and have been used for rhamnolipids production using $P$. aeruginosa ATCC 10145, giving a rhamnose concentration of $6.9 \mathrm{~g} / \mathrm{L}$ and biosurfactant concentration of $11.7 \mathrm{~g} / \mathrm{L}$ [49]. Molasses distillery wastewater was used as a substrate for rhamnolipids production by $P$. aeruginosa GIM32 and the yield reached $2.6 \mathrm{~g} / \mathrm{L}$ [50]. Pseudomonas aeruginosa strain BS2 was able to use distillery waste from the alcohol industry and curd whey waste from the milk industry as substrates for rhamnolipids production and the yields reached 0.91 and $0.92 \mathrm{~g} / \mathrm{L}$, respectively [51].

Sugarcane molasses is the final effluent of sugar refinement and comprises approximately $40 \%(\mathrm{w} / \mathrm{w})$ sugars. The molasses is normally used as an ingredient in some

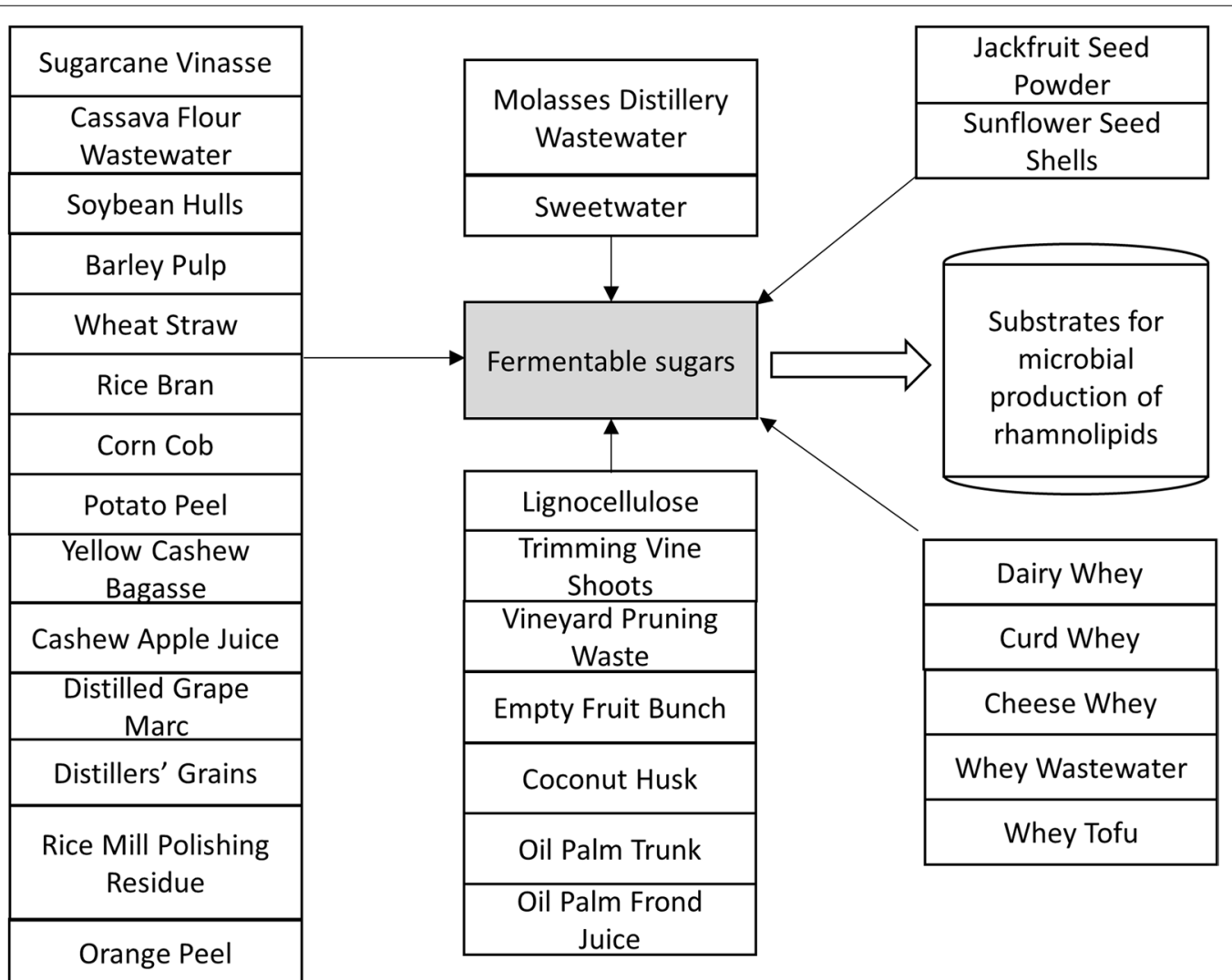

Fig. 2 Sugar-containing wastes that can be used as carbon sources for rhamnolipids production. Many wastes contain high amounts of sugars or can be converted into sugars using chemical and enzymatic reactions 
Table 1 Biosurfactant production using sugar-containing wastes

\begin{tabular}{|c|c|c|c|}
\hline Sugar source & Strain & Biosurfactant yield & References \\
\hline \multirow[t]{3}{*}{ Barley pulp } & P. aeruginosa ATCC 9027 & $9.3 \mathrm{~g} / \mathrm{L}$ & [73] \\
\hline & P. pachastrellae LOS20 & $9.2 \mathrm{~g} / \mathrm{L}$ & [73] \\
\hline & P.putida IBS036 & $2.4 \mathrm{~g} / \mathrm{L}$ & [73] \\
\hline Barley bran husk & Lactobacillus pentosus & $0.28 \mathrm{~g} / \mathrm{g}$ biomass & [94] \\
\hline \multirow[t]{2}{*}{ Bean cake } & Bacillus amyloliquefaciens XZ-173 & $2.18 \mathrm{mg} / \mathrm{gds}$ & [139] \\
\hline & Bacillus amyloliquefaciens XZ-173 & $14.61 \mathrm{mg} / \mathrm{gds}$ & [140] \\
\hline Cashew apple juice & Acinetobacter calcoaceticus & N.A. & {$[75]$} \\
\hline Yellow cashew & P. aeruginosa & $7.1-9.3 \mathrm{~g} / \mathrm{L}$ & {$[74]$} \\
\hline \multirow[t]{3}{*}{ Cassava wastewater } & $P$. aeruginosa & $169.9-300.3 \mathrm{mg} / \mathrm{L}$ & [104] \\
\hline & P. fluorescens & N.A. & [103] \\
\hline & Pseudozyma tsukubaensis & $8.11 \mathrm{~g} / \mathrm{L}$ & [105] \\
\hline \multirow[t]{3}{*}{ Corncob hydrolysate } & Starmerella bombicola & $33.7-49.2 \mathrm{~g} / \mathrm{L}$ & [141] \\
\hline & B. subtilis BS-37 & $523 \mathrm{mg} / \mathrm{L}$ & [142] \\
\hline & Lactobacillus pentosus & $0.53 \mathrm{~g} / \mathrm{g}$ biomass & [94] \\
\hline \multirow[t]{2}{*}{ Corn flour } & Bacillus amyloliquefaciens XZ-173 & $1.56 \mathrm{mg} / \mathrm{gds}$ & [139] \\
\hline & Bacillus amyloliquefaciens XZ-173 & $8.38 \mathrm{mg} / \mathrm{gds}$ & [140] \\
\hline Eucalyptus globulus chips & Lactobacillus pentosus & $0.54 \mathrm{~g} / \mathrm{g}$ biomass & [94] \\
\hline Raw cheese whey & P. aeruginosa ATCC 10145 & $9.6 \mathrm{~g} / \mathrm{L}$ & [99] \\
\hline Paneer whey & P. aeruginosa SR17 & $2.7-4.8 \mathrm{~g} / \mathrm{L}$ & [98] \\
\hline \multirow[t]{3}{*}{ Whey wastewater } & Yarrowia lipolytica MFW5 & N.A. & [101] \\
\hline & Micrococcus luteus MFW1 & N.A. & [101] \\
\hline & Burkholderia cepacia MFW2 & N.A. & [101] \\
\hline \multirow[t]{2}{*}{ Curd whey } & $P$. aeruginosa BS2 & $0.92 \mathrm{~g} / \mathrm{L}$ & [51] \\
\hline & $P$. aeruginosa BS-P & $1.63 \mathrm{~g} / \mathrm{L}$ & [78] \\
\hline \multirow[t]{2}{*}{ Distillers' grains } & Bacillus amyloliquefaciens MT45 & $1.04 \mathrm{~g} / \mathrm{L}$ & [143] \\
\hline & Bacillus amyloliquefaciens MT45 \& X82 & $3.4 \mathrm{~g} / \mathrm{L}$ & [143] \\
\hline Distilled grape marc hydrolysate & Lactobacillus pentosus & N.A. & {$[80]$} \\
\hline \multirow[t]{2}{*}{ Distillery waste } & P. aeruginosa BS2 & $0.91 \mathrm{~g} / \mathrm{L}$ & [51] \\
\hline & $P$. aeruginosa BS-P & $1.42 \mathrm{~g} / \mathrm{L}$ & [78] \\
\hline \multirow[t]{3}{*}{ Hazelnut pulp } & P. aeruginosa ATCC 9027 & $11.1 \mathrm{~g} / \mathrm{L}$ & [73] \\
\hline & P. pachastrellae LOS20 & $5.4 \mathrm{~g} / \mathrm{L}$ & [73] \\
\hline & P. putida IBS036 & $8.5 \mathrm{~g} / \mathrm{L}$ & [73] \\
\hline \multirow[t]{11}{*}{ Molasses } & P. aeruginosa GS3 & $0.24 \mathrm{~g} / \mathrm{L}$ & {$[55]$} \\
\hline & Marine $P$. aeruginosa & $3.4-3.9 \mathrm{~g} / \mathrm{L}$ & [63] \\
\hline & Bacillus licheniformis TR7 & $3.3 \mathrm{~g} / \mathrm{L}$ & [56] \\
\hline & B. subtilis SA9 & $3.78 \mathrm{~g} / \mathrm{L}$ & [56] \\
\hline & P. fluorescens & N.A. & [53] \\
\hline & B. subtilis R1 & N.A. & [144] \\
\hline & Bacillus licheniformis K51 & N.A. & [144] \\
\hline & B. subtilis 20B & N.A. & [144] \\
\hline & Bacillus HS3 & N.A. & [144] \\
\hline & B. subtilis MTCC 1427 & N.A. & [54] \\
\hline & B. subtilis MTCC 2423 & N.A. & [54] \\
\hline Date molasses & B. subtilis B30 & $0.3 \mathrm{~g} / \mathrm{L}$ & [145] \\
\hline Molasses distillery wastewater & P. aeruginosa GIM32 & $2.6 \mathrm{~g} / \mathrm{L}$ & {$[50]$} \\
\hline Orange peel & P. aeruginosa MTCC 2297 & $9.18 \mathrm{~g} / \mathrm{L}$ & [77] \\
\hline Potato peel & DGEF01-06 & N.A. & {$[76]$} \\
\hline \multirow[t]{2}{*}{ Rapeseed meal } & Bacillus amyloliquefaciens XZ-173 & $2.68 \mathrm{mg} / \mathrm{gds}$ & [139] \\
\hline & Bacillus amyloliquefaciens XZ-173 & $15.16 \mathrm{mg} / \mathrm{gds}$ & [140] \\
\hline
\end{tabular}


Table 1 (continued)

\begin{tabular}{|c|c|c|c|}
\hline Sugar source & Strain & Biosurfactant yield & References \\
\hline Rice mill processing residue & B. subtilis MTCC 2423 & $4.17 \mathrm{~g} / \mathrm{kg}$ substrate & [146] \\
\hline Soy pulp & Bacillus pumilus UFPEDA 448 & $809 \mathrm{mg} / \mathrm{L}$ & [147] \\
\hline \multirow[t]{2}{*}{ Soybean flour } & Bacillus amyloliquefaciens XZ-173 & $4.39 \mathrm{mg} / \mathrm{gds}$ & [139] \\
\hline & Bacillus amyloliquefaciens XZ-173 & $38.42 \mathrm{mg} / \mathrm{gds}$ & [140] \\
\hline Soy molasses & P. aeruginosa ATCC 10145 & $11.7 \mathrm{~g} / \mathrm{L}$ & [49] \\
\hline Whey tofu & P.fluorescens & N.A. & [102] \\
\hline \multirow[t]{2}{*}{ Sugar beet molasses } & P. luteola B17 & $0.53 \mathrm{~g} / \mathrm{L}$ & [59] \\
\hline & P. putida B12 & $0.52 \mathrm{~g} / \mathrm{L}$ & [59] \\
\hline Sugarcane bagasse & P. aeruginosa ATCC 10145 & $9.1 \mathrm{~g} / \mathrm{L}$ & [57] \\
\hline Sugarcane vinasse & P. aeruginosa PA1 & $2.7 \mathrm{~g} / \mathrm{L}$ & [58] \\
\hline \multirow[t]{3}{*}{ Sunflower pulp } & P. aeruginosa ATCC 9027 & $5.3 \mathrm{~g} / \mathrm{L}$ & [73] \\
\hline & P. pachastrellae LOS20 & $5 \mathrm{~g} / \mathrm{L}$ & {$[73]$} \\
\hline & P.putida IBS036 & $6.7 \mathrm{~g} / \mathrm{L}$ & [73] \\
\hline Sunflower seed shell & Pleurotus djamor & $10.2 \mathrm{~g} / \mathrm{L}$ & [148] \\
\hline Sweetwater & Marine $P$. aeruginosa & $4.0-4.7 \mathrm{mg} / \mathrm{L}$ & [63] \\
\hline \multirow[t]{2}{*}{ Trimming vine shoots } & Lactobacillus pentosus & $0.71 \mathrm{~g} / \mathrm{g}$ biomass & [94] \\
\hline & Lactobacillus pentosus & N.A. & [95] \\
\hline Vineyard pruning waste & Lactobacillus paracasei & N.A. & [79] \\
\hline \multirow[t]{2}{*}{ Wheat bran } & Bacillus amyloliquefaciens XZ-173 & $2.74 \mathrm{mg} / \mathrm{gds}$ & [139] \\
\hline & Bacillus amyloliquefaciens XZ-173 & $13.17 \mathrm{mg} / \mathrm{gds}$ & [140] \\
\hline Wheat straw & P. aeruginosa NCIM 2036 & $9.38 \mathrm{~g} / \mathrm{L}$ & {$[6]$} \\
\hline
\end{tabular}

food products and it has impact on immune system [52]. Adding molasses into the medium is able to increase rhamnolipids production by $P$. fluorescens and enhance phenol degradation [53]. Other bacteria such as Bacillus subtilis (B. subtilis) (MTCC 2423 and MTCC1427) were reported to utilize sugarcane molasses for biosurfactant production at $45^{\circ} \mathrm{C}$ [54]. The yield of rhamnolipids reached $0.24 \mathrm{~g} / \mathrm{L}$ when $P$. aeruginosa $\mathrm{GS} 3$ was grown in a medium that contained molasses and corn steep liquor [55]. Bacillus licheniformis TR7 and B. subtilis SA9 grown on molasses produced biosurfactant at 3.3 and $3.78 \mathrm{~g} / \mathrm{L}$, respectively [56]. In addition, exploded sugarcane bagasse has been utilized to co-produce rhamnolipids $(9.1 \mathrm{~g} / \mathrm{L})$ and ethanol $(8.4 \mathrm{~g} / \mathrm{L})$ using Saccharomyces cerevisiae, $P$. aeruginosa and crude enzyme complexes (CECs) [57]. The CECs were produced by Aspergillus niger in solid-state fermentation using different levels of exploded sugarcane bagasse, rice bran and corn cob as substrates [57].

\section{Sugarcane vinasse}

Sugarcane vinasse, a residue from bioethanol production is a common waste during fermentation using substrate from sugar crops. It also contains sugars and is able to serve as a substrate for rhamnolipids production [58]. Pseudomonas aeruginosa PA1 could produce $2.7 \mathrm{~g} / \mathrm{L}$ of rhamnolipids when sugarcane vinasse was used as a substrate in submerged fermentation [58]. Pseudomonas luteola B17 and P. putida B12 grown on autoclaved medium consisting of sugarcane beet molasses mixed with distilled water, gave maximum rhamnolipids production at $72 \mathrm{~h}$ [59]. Other strains such as B. subtilis can also use sugarcane vinasse as sources for biosurfactant and energy production [60-62]. In addition to vinasse and molasses, sugar cane refining by-products such as sweet water have also been used as carbon sources for $P$. aeruginosa with rhamnolipids yields of 4.0-4.7 g/L [63].

\section{Lignocellulose}

Lignocellulose is present in agricultural products, which makes many related wastes or byproducts attractive low-cost substrates for biosurfactant production. Lignocellulosic biomass has been used as an alternative cost-effective substrate for the microbial production of rhamnolipids as it can be converted into fermentable sugars. It has been noted that pretreatment is required to convert lignocellulosic biomass to fermentable sugars because several enzymes are required for the cellulose degradation (Fig. 3). Converting cellulose to fermentable sugars has been well studied. Pretreatment-a step to obtain cellulose is required, which is a critical step for later enzymatic process as the lignin and other components may affect enzymatic activities or prevent enzyme from accessing cellulose $[64,65]$. Cell-degrading enzymes 


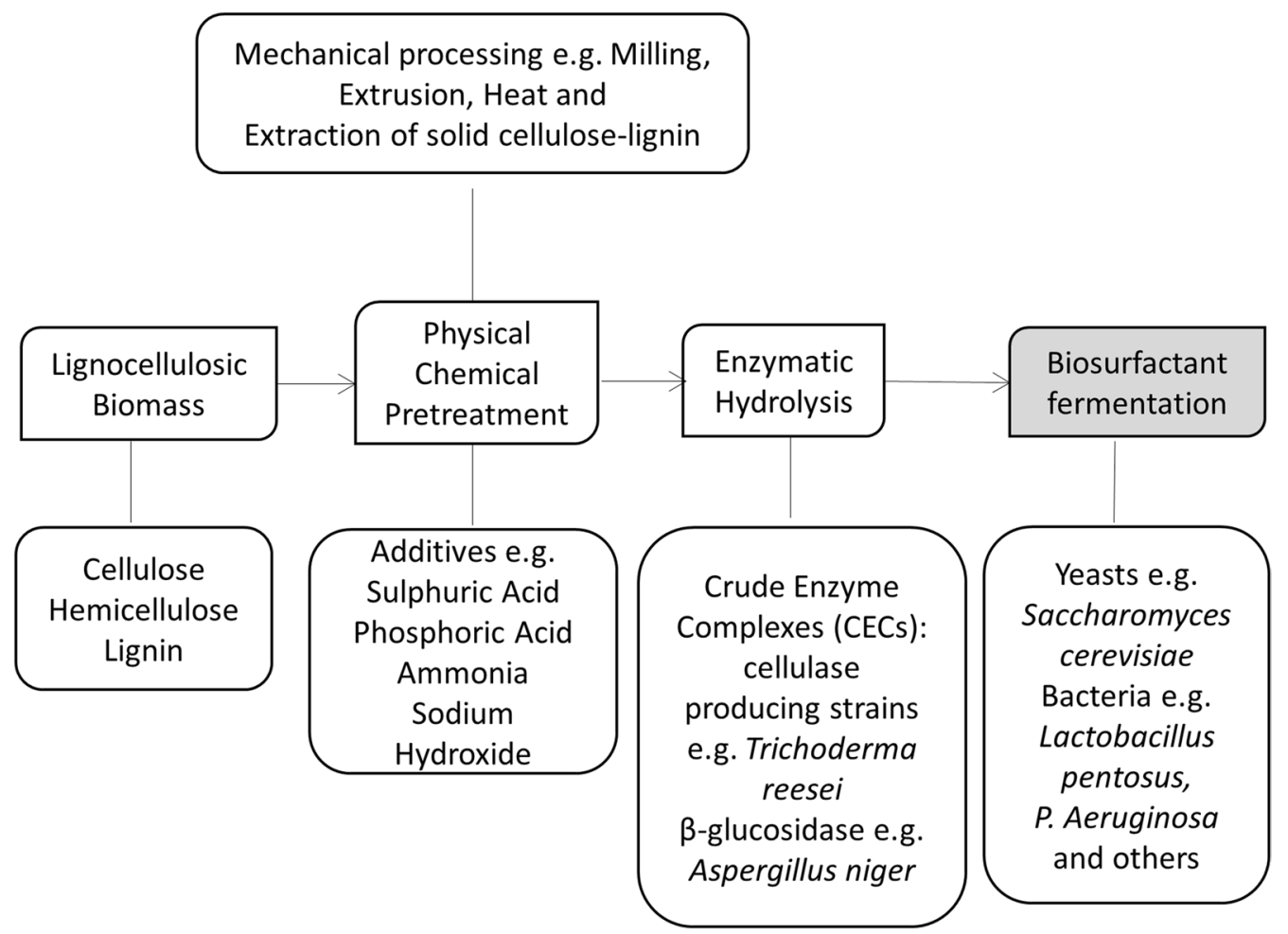

Fig. 3 Treatment of cellulose to obtain fermentable sugars for biosurfactant production. Pretreatment of cellulose is required to obtain fermentable sugars. Normally both acid pretreatment and enzymatic hydrolysis are required for sugar production. The produced sugars can be used for microbial production of rhamnolipids

or stains will be mixed with cellulose to obtain fermentable sugars which can serve as carbon sources for microorganisms [66]. While lignocellulosic biomass pretreatment is an important topic, it has been introduced in literatures [67-72] and will not be elucidated here.

\section{Wheat straw}

Pretreatment of wheat straw with sulphuric acid, phosphoric acid and ammonia and then followed by enzymatic hydrolysis with cellulases from Trichoderma reesei NCIM 1186 could obtain sugars [6]. The resulting sugars were used to produce rhamnolipids $(9.38 \mathrm{~g} / \mathrm{L})$ by $P$. aeruginosa NCIIM 2036 [6]. Similar to wheat straw, lignocellulose-containing wastes such as barley pulp have been used for rhamnolipids production using $P$. aeruginosa ATCC 9027 and the yield of rhamnolipids reached $2.4 \mathrm{~g} / \mathrm{L}$ [73]. Addition of glycerol to the media could increase rhamnolipids yield to $9.3 \mathrm{~g} / \mathrm{L}$ [73].

\section{Waste from fruit products}

In addition to wheat straw, yellow cashew fruit bagasse was crushed into powder and mixed with basal mineral medium for rhamnolipids production using $P$. aeruginosa [74]. Cashew apple juice was shown to serve as a medium for Acinetobacter calcoaceticus growth and biosurfactant production [75]. Potato peel mixed with urea was able to affect biosurfactant production positively [76]. Pseudomonas aeruginosa ATCC 2297 could produce $9.18 \mathrm{~g} / \mathrm{L}$ of rhamnolipids using orange peel as carbon sources [77]. Fruit-processing waste and sugar industry effluent were also found to be viable substrates for biosurfactant fermentation by $\mathrm{Kocu}$ ria turfanesis and P. aeruginosa [78]. As part of whole waste recycling, vineyard pruning waste was collected and acid hydrolysis was performed to remove the hemicellulosic sugars [79]. The remaining lignocellulosic fraction was undergoing delignification. The cellulosic fraction was then subjected to enzymatic hydrolysis using cellulase and $\beta$-glucosidase to obtain cellulosic sugars. The sugars were then used in fermentation as a low-cost carbon source for biosurfactant production by Lactobacillus paracasei [79]. Distilled grape marc was also discovered to be a low-cost feedstock of sugars for biosurfactant production by Lactobacillus pentosus, with values of relative emulsion volume close to $50 \%$ and stabilizing capacity values to maintain the emulsion at 99\% [80]. 


\section{Byproducts and wastes from oil production}

Oil palm trees are currently very abundant in Southeast Asia for palm oil production and the wastes generated are an untapped resource for biosurfactants production. The byproducts from oil production are rich in cellulose. For example empty fruit bunch (EFB) was converted to fermentable sugars using dilute sulphuric to solubilize hemicellulose and cellulase enzymes produced by Trichoderma reesei RUT-C30 (ATCC 56765) to hydrolyze cellulose giving a total sugar yield of $82 \%$ [65]. The product was proven to be suitable for cell growth and serve as a potential medium for rhamnolipids production [65]. Palm kernel cake, a solid residue that remains after oil extraction from the kernels of palm fruits, has been identified as a potential low-cost substrate for biosurfactant production due to its high mineral, protein and fatty acid contents [81]. Providencia alcalifaciens SM03 was isolated from degraded palm kernel cake and shown to produce glycolipids at $8.3 \mathrm{~g} / \mathrm{L}$ [81]. A study made use of $25 \%$ $(\mathrm{v} / \mathrm{v})$ palm oil decanter cake mixed with $1 \%$ monosodium glutamate as an optimized media in microbial cultivation [82]. Ochrobactrum anthropi $2 / 3$ was able to produce $4.52 \mathrm{~g} / \mathrm{L}$ glycolipid biosurfactant after cultivation at $30{ }^{\circ} \mathrm{C}$ for $96 \mathrm{~h}$ [82].

Palm oil mill effluent is a waste by-product from the wet process of palm oil milling which requires 5-7.5 tons of water to produce 1 ton of crude palm oil. Rich in fermentable sugars and nitrogenous compounds, palm oil mill effluent has been used as a fermentation media for microbial production of surfactin by $B$. subtilis ATCC 21332 [83]. Palm oil mill effluent has also been successfully used by Nevskia ramose NA3 for biosurfactant production [84]. Felled oil palm trunks contains glucose (approximately $85.2 \mathrm{~g} / \mathrm{L}$ ) in its sap, as well as low concentrations of sucrose, fructose, galactose, xylose and rhamnose, serving as a significant source for fermentation by yeast strains [85]. Pressed juice from oil palm fronds have also been reported to contain $53.95 \mathrm{~g} / \mathrm{L}$ glucose and other sugars such as sucrose and fructose [86]. To utilize the oil palm trunk efficiently, it is first separated into sap and trunk fiber, where the sap is used directly while the trunk fiber is hydrolyzed to fermentable sugars using sulphuric acid [87]. The bioconversion of oil palm trunk waste into sugars via the lignocellulosic route indicates its promising potential as a renewable substrate for rhamnolipids production.

Several studies have been conducted to utilize olive mill waste as a carbon source in biosurfactant production [88]. Enzymatic hydrolysis of olive mill waste using a mixture of cellulases, hemicellulases and xylanase was carried out at $50{ }^{\circ} \mathrm{C}$ with agitation. Fermentation with $P$. aeruginosa and $B$. subtilis achieved 29.5 and $13.7 \mathrm{mg} / \mathrm{L}$ of rhamnolipids and surfactins, respectively
[89]. Various Pseudomonas strains were found to be able to grow on olive oil mill effluent (OOME) mixed with $0.25 \mathrm{~g} / \mathrm{L}$ sodium nitrate to produce $0.058 \mathrm{~g}$ rhamnolipids per g of OOME substrate [90]. It was demonstrated that $P$. aeruginosa could produce $5.1 \mathrm{~g} / \mathrm{L}$ of rhamnolipids in a medium in which olive mill waste $(25 \% \mathrm{v} / \mathrm{v})$ was mixed with corn steep liquor $(10 \% \mathrm{v} / \mathrm{v})$ and sugarcane molasses $(10 \% \mathrm{w} / \mathrm{v})$ [91]. Another similar study reported that $P$. aeruginosa produced $191.46 \mathrm{mg} / \mathrm{L}$ rhamnolipids with $10 \% \mathrm{w} / \mathrm{v}$ olive mill waste while $B$. subtilis produced $3.12 \mathrm{mg} / \mathrm{L}$ surfactin with $2 \% \mathrm{w} / \mathrm{v}$ olive mill waste [92]. Coconut oil sludge and oil cake, another agro-industrial residue, has been used as a carbon source for rhamnolipids production by $P$. aeruginosa AMB AS7, achieving a maximum biosurfactant concentration of $5.53 \mathrm{~g} / \mathrm{L}$ during $60 \mathrm{~h}$ of cultivation at $37^{\circ} \mathrm{C}$ and $120 \mathrm{rpm}$ [93].

\section{Other agricultural residues}

Agricultural residues such as barley bran, trimming vine shoots and corn cobs were used in biosurfactant production. To obtain the carbon source, the lignocellulosic residues was first treated with sulphuric acid and neutralizing with calcium carbonate. Yeast extract and corn steep liquor were served as nitrogen sources for Lactobacillus pentosus which could produce 0.71 and $0.28 \mathrm{~g}$ of biosurfactant per $g$ of biomass from trimming vine shoots and barley bran husk hydrolysates, respectively [94]. In a similar study, trimming vine shoots were utilized by Lactobacillus pentosus hydrolysates for both lactic acid and biosurfactant production [95]. The trimming vine shoots first underwent acidic pre-hydrolysis to convert the hemicellulose polysaccharides (xylan, mannan and galactan) into corresponding monosaccharides (xylose, mannose and glucose). The hydrolyzed trimming vine shoots produced a fermentation medium containing $18 \mathrm{~g} / \mathrm{L}$ xylose, $11.1 \mathrm{~g} / \mathrm{L}$ glucose and $4.3 \mathrm{~g} / \mathrm{L}$ of arabinose [95]. Lactobacillus pentosus could produce lactic acid and xylose to lactic acid (60\%) and acetic acid (40\%), and produces biosurfactants as part of the cell membrane [95]. Other bacteria such as Acinetobacter, B. subtilis and Pseudomonas are able to produce biosurfactants using such wastes [41]. It has been noted that all these mentioned carbon sources can be used for biosurfactant production by fungus which can produce different types of biosurfactant [96].

In addition to the aforementioned waste, Jackfruit, a tree that grows in tropical countries in Southeast Asia, comprises of 100-300 seeds in a single fruit. Jackfruit seeds have high carbohydrate and protein content, making up $10-15 \%$ of the total fruit mass, but are usually discarded. One study has utilized the jackfruit seeds as an abundant and low-cost substrate for biosurfactant production. Deinococcus caeni PO5 was shown to produce 
$3.12 \mathrm{~g} / \mathrm{L}$ glycolipid biosurfactant when grown on an optimized medium containing jackfruit seed powder [97].

\section{Whey products}

Dairy whey, milk serum which is generated after curdling of milk or coagulation of casein, is also a potential medium for rhamnolipids production. Whey contains lactose and proteins which can serve as carbon and nitrogen sources for microorganisms. Pseudomonas aeruginosa SR17 was able to produce rhamnolipids in the presence of paneer whey with a yield of $2.7 \mathrm{~g} / \mathrm{L}$ [98]. The yield was further improved to $4.8 \mathrm{~g} / \mathrm{L}$ when the paneer whey medium was supplemented with $2 \%$ glucose and mineral salts [98]. Another study showed that $P$. aeruginosa ATCC 10145 cultivated in raw cheese whey at $37^{\circ} \mathrm{C}$ could produce $9.6 \mathrm{~g} / \mathrm{L}$ rhamnolipids after $72 \mathrm{~h}$ [99]. Lactobacillus pentosus CECT-4023 was capable of producing biosurfactants in a medium containing cheese whey at $1.4 \mathrm{~g} / \mathrm{L}[41,100]$. Yarrowia lipolytica MFW5, Micrococcus luteus MFW1 and Burkholderia cepacia MFW2 produced biosurfactants in whey wastewaters from the milk factory [101]. Whey tofu-a waste during tofu production was shown to be a viable medium for rhamnolipids production by P. fluorescens [102].

\section{Cassava}

Cassava flour wastewater mixed with nutrient broth was served as a medium for rhamnolipids production by $P$. fluorescens [103]. When solid residues were removed from cassava wastewater and autoclaved for use as a growth medium for various $P$. aeruginosa strains, rhamnolipids yields between 169.9 and $300.3 \mathrm{mg} / \mathrm{L}$ were achieved [104]. One study showed an integrated process in which $10.5 \mathrm{~g} / \mathrm{L}$ of biosurfactant was first produced by Pseudozyma tsukubaensis, and the resulting microbial cells were used to synthesize galactooligosaccharides from lactose [105].

\section{Challenges}

Rhamnolipids are formed by hydrophilic L-rhamnose (mono-rhamnolipids) or L-rhamnopyranosyl-2-O-aL-rhamnopyranoside (di-rhamnolipids) linked through an $\alpha$-glycosidic bond to a hydrophobic moiety such as HAA, which are saturated or unsaturated fatty acids with alkyl chain length varying from 8 up to 16 carbon molecules. The biosynthesis and proportion of rhamnolipids types produced is dependent on nutritional and environmental conditions during microbial growth [106]. Challenges remain when sugars or sugar-containing wastes are used for rhamnolipids production.

\section{Rhamnolipids purification}

The production of mono- or di-rhamnolipids depends on the regulation of the sequential induction of rhlAB and rhlC operons. When glucose is used as the carbon source, rhlAB and rhlC operons are simultaneously activated under the same QS mechanism. RhlA is involved in the production of HAAs, RhlB adds a rhamnose ring to the HAA precursor to form mono-rhamnolipids, and rhlC to catalyze the addition of the second rhamnose molecule to mono-rhamnolipids to synthesize di-rhamnolipids. However, in an oil-containing carbon source, rhlAB expression is not switched off, resulting in delayed transcriptional activation of rhlC to give rise to a major production of mono-rhamnolipids [107]. Purification of rhamnolipids can be achieved using conventional methods including solvent extraction or chromatography while these methods are time consuming. Foam fractionation is an efficient way for rhamnolipids purification $[106,108,109]$ and the purity of rhamnolipids will be affected when oil-type carbon sources are used in fermentation as a carbon source as products have similar structures or form complexes with the substrates. Using sugar-type carbon sources will make the down-stream process relatively easy while it is still challenging to obtain pure mono- and di-rhamnolipid, respectively.

\section{Low yields from sugar-type substrates}

Different metabolic pathways for hydrophilic and hydrophobic substrates synthesize different precursors for biosurfactant production. This provides an explanation for the various yields resulting from different carbon sources in the culture medium. When a glucose carbon source is used, both the lipogenic pathway and glycolytic pathway are suppressed by cell metabolism. Glucose is degraded until intermediate glucose-6-phosphate is formed. In order to form lipids, glucose has to be oxidized to pyruvate, then converted to acetyl-CoA, which is finally transformed to a fatty acid. However, when oils are used as the carbon source, gluconeogenesis is activated to produce sugars by oxidizing fatty acids through $\beta$-oxidation to acetyl-CoA. Polysaccharide precursor glucose-6-phosphate is then synthesized to form glucose. This gives rise to the hypothesis that oil-containing carbon sources produce higher yields of biosurfactants compared to sugars [110]. For example, P. aeruginosa and P. fluorescens were cultivated in mineral medium supplemented with vegetable oil, sucrose and octanoate and rhamnolipids production was the highest $(174 \mathrm{mg} / \mathrm{L})$ when vegetable oil was used as the carbon source [111]. The yield of rhamnolipid is higher when oil-type carbon sources are used in the culture media [112-114]. The yield of rhamnolipids reached $36.7 \mathrm{~g} / \mathrm{L}$ when $P$. aeruginosa was grown in a 
medium containing sunflower oil [115]. It has been noted that altering the components of the medium can improve rhamnolipids yields when glucose was used as a carbon source [116].

\section{Fermentation condition optimization}

Sugars derived from wastes contain several types of hydrocarbons, making fermentation control complicated. Studies comparing the variation within one type of carbon source were carried out. Oceanobacillus sp. BRI 10 was cultivated in a basal salt medium containing glucose, sugarcane juice, whey and commercial table sugar respectively, and sugarcane juice was found to produce the highest yield of biosurfactant [117]. High total sugar content (34-76\% dry weight) was present in corn powder, potato peel powder and sugarcane bagasse compared to wheat straw, soybean powder and rice husk [118]. An alkaliphilic bacterium Klebsiella sp. Strain RJ-03 could produce $15.4 \mathrm{~g} / \mathrm{L}$ biosurfactant in a medium supplied with corn powder [118]. Study has also shown that usage of a combination of sugar and oil sources enable optimal biosurfactant production. Candida (Starmerella) bombicola was cultivated on different lignocellulose hydrolysates-sweet sorghum bagasse and corn fiber, producing a sophorolipid yield of 3.6 and $1.0 \mathrm{~g} / \mathrm{L}$ respectively. However, when soybean oil was added at $100 \mathrm{~g} / \mathrm{L}$, sophorolipid yield increased drastically to 84.6 and $15.6 \mathrm{~g} / \mathrm{L}$ in sweet sorghum bagasse and corn fiber. This shows that cultures with both monomeric sugars and non-sugar compounds in biomass hydrolysates generated higher biosurfactant yield than a glucose medium with similar concentration [119]. A similar conclusion was drawn in another study, where the yeast Candida bombicola grown on low cost media based on sugarcane molasses and soybean oil produced $23.25 \mathrm{~g} / \mathrm{L}$ of sophorolipids, comparable to conventional synthetic medium [120].

\section{Carbon sources affect rhamnolipids yields}

It is known that different carbon sources give rise to various rhamnolipid yields [107]. Mixture of different types of carbon sources are used in rhamnolipid production. Mixtures of glucose and fatty acids with different chain lengths $\left(\mathrm{C}_{12}-\mathrm{C}_{22}\right)$ and saturation were used to compare the effect of fatty acid substrates on rhamnolipids yield. Experimental results showed that 1\% glucose and $0.25 \%$ stearic acid $\left(\mathrm{C}_{18}\right)$ produced $2.1 \mathrm{~g} / \mathrm{L}$ of rhamnolipids. The yields reached $14.3 \mathrm{~g} / \mathrm{L}$ using $2 \%$ glucose and $2 \%$ stearic acid $\left(\mathrm{C}_{18}\right)$. Generally, P. aeruginosa ATCC 9027 produced an increasing rhamnolipids yield with increasing fatty acid with chain length ranging from $C_{12}$ to $C_{18}$ [121]. When a sugar carbon source is selected, extensive experiments are required to obtain the optimal fermentation conditions.

\section{Sugar yield from lignocellulose}

Despite intensive research to improve the release of fermentable sugars from lignocellulose, efficient hydrolysis of lignocellulose by enzymes remains challenging [122]. Lignin is adsorbed on cellulolytic enzymes, which blocks the access of cellulolytic enzymes to the substrate, hinders the removal of cellulase from cellulose, and reduces substrate hydrolysis [123]. Many studies have been carried out to improve the sugar yield from lignocellulose biomass. Addition of tea saponin to corncob residue during enzymatic hydrolysis enhanced the glucose yield from 34.29 to $46.28 \mathrm{~g} / 100 \mathrm{~g}$ [124]. In another study, twostage co-hydrolysis by Trichoderma reesei and $P$. aeruginosa BSZ-07 increased the production of reducing sugars $(2.57 \mathrm{~g} / \mathrm{L})$ in rice straw by $15.2 \%$ [125]. Another example is elephant grass which requires pretreatment with sodium hydroxide and addition of Tween 80 surfactant to increase the efficiency of releasing reducing sugars for fermentation [126].

\section{Perspective}

Rhamnolipids can be produced using sugars as carbon sources by bacteria such as $P$. aeruginosa and other nonpathogenic strains $[45,127-129]$. It is known that less purification steps are required when sugars are used as carbon sources for rhamnolipids production. Although sugars such as glucose are commercially available as fermentation sources, these sugars are produced from food resources. When the produced rhamnolipids are used in large quantities, obtained sugars from a different resource is absolutely needed. To reduce production cost derived from carbon sources, sugar-containing wastes or a waste that can be converted into sugars are a good candidate as carbon sources for rhamnolipids production. The most abundant sugar containing material is cellulose $[130,131]$. Therefore, wastes from agricultural products can be used as a carbon source for rhamnolipids production. The cellulose-containing wastes are normally much cheaper than sugar containing waste while converting cellulose to sugars is required before its application as carbon sources for rhamnolipids production. Converting cellulose to sugars has been well studied for decades $[64,66,132]$. Several methods can be used to convert cellulose into fermentable sugars [133-136]. Therefore, it is feasible to use these wastes for rhamnolipids production. These wastes are very promising when the rhamnolipids product is used in some fields which does not require purified biosurfactant.

In addition to rhamnolipids, other biosurfactants can be produced using cellulose-containing wastes as carbon 
sources $[137,138]$. The accumulated experience is also useful for guiding rhamnolipids production using strains such as $P$. aeruginosa. Other parameters that can be used to reduce rhamnolipids production cost include using more powerful strains, an optimized fermentation procedure, an efficient sugar processing strategy, and an easy purification step [15]. Nonetheless, using sugars derived from cellulose-containing material as a carbon source is a good choice for rhamnolipids production at a low cost. More work needs to be carried out to explore a suitable conditions for large-scale rhamnolipids production using sugar-containing wastes, especially for the wastes that requires pretreatment.

\section{Authors' contributions}

YNT and QL drafted and revised the manuscript. Both authors read and approved the final manuscript.

\section{Author details}

${ }^{1}$ School of Chemical and Biomedical Engineering, Nanyang Technological University, 62 Nanyang Drive, Singapore 637459, Singapore. ${ }^{2}$ Institute of Chemical and Engineering Sciences, Agency for Science, Technology and Research, 1 Pesek Road, Singapore, Jurong Island 627833, Singapore.

\section{Acknowledgements}

This work was supported by the Institute of Chemical and Engineering Sciences (ICES) and the Science and Engineering Research Council (SERC) of the Agency for Science, Technology and Research (A*STAR) of Singapore (SERC Grant Number 1526004161).

\section{Competing interests}

The authors declare that they have no competing interests.

Ethics approval and consent to participate

Not applicable.

\section{Publisher's Note}

Springer Nature remains neutral with regard to jurisdictional claims in published maps and institutional affiliations.

Received: 20 February 2018 Accepted: 31 May 2018

Published online: 08 June 2018

\section{References}

1. Prasad B, Kaur HP, Kaur S. Potential biomedical and pharmaceutical applications of microbial surfactants. World J Pharm Pharm Sci. 2015:4:1557-75

2. Shekhar S, Sundaramanickam A, Balasubramanian T. Biosurfactant producing microbes and their potential applications: a review. Crit Rev Environ Sci Technol. 2015;45:1522-54.

3. Amaral PF, Coelho MA, Marrucho IM, Coutinho JA. Biosurfactants from yeasts: characteristics, production and application. Adv Exp Med Biol. 2010;672:236-49.

4. Usman MM, Dadrasnia A, Lim KT, Mahmud AF, Ismail S. Application of biosurfactants in environmental biotechnology; remediation of oil and heavy metal. AIMS Bioeng. 2016;3:289-304.

5. Ndlovu T, Khan S, Khan W. Distribution and diversity of biosurfactantproducing bacteria in a wastewater treatment plant. Environ Sci Pollut Res Int. 2016;23:9993-10004.

6. Prabu R, Kuila A, Ravishankar R, Rao PVC, Choudary NV, Velankar HR. Microbial rhamnolipid production in wheat straw hydrolysate supplemented with basic salts. RSC Adv. 2015;5:51642-9.
7. Lovaglio RB, Silva VL, Ferreira H, Hausmann R, Contiero J. Rhamnolipids know-how: looking for strategies for its industrial dissemination. Biotechnol Adv. 2015;33:1715-26.

8. Kim LH, Jung Y, Kim SJ, Kim CM, Yu HW, Park HD, Kim IS. Use of rhamnolipid biosurfactant for membrane biofouling prevention and cleaning. Biofouling. 2015;31:211-20.

9. Sobrinho HB, Luna JM, Rufino RD, Porto ALF, Sarubbo LA. Biosurfactants: classification, properties and environmental applications. Biotechnology. 2014;11:1-29.

10. Mnif I, Ellouz-Chaabouni S, Ghribi D. Glycolipid biosurfactants, main classes, functional properties and related potential applications in environmental biotechnology. J Polym Environ. 2017;26(5):2192-206.

11. Müller MM, Kügler JH, Henkel M, Gerlitzki M, Hörmann B, Pöhnlein M, Syldatk C, Hausmann R. Rhamnolipids—next generation surfactants? J Biotechnol. 2012;162:366-80.

12. Henkel M, Müller MM, Kügler JH, Lovaglio RB, Contiero J, Syldatk C, Hausmann R. Rhamnolipids as biosurfactants from renewable resources: concepts for next-generation rhamnolipid production Process Biochem. 2012;47:1207-19.

13. Perfumo A, Rudden M, Smyth TJ, Marchant R, Stevenson PS, Parry NJ, Banat IM. Rhamnolipids are conserved biosurfactants molecules: implications for their biotechnological potential. Appl Microbiol Biotechnol. 2013;97:7297-306.

14. Geys R, Soetaert W, Bogaert IV. Biotechnological opportunities in biosurfactant production. Curr Opin Biotechnol. 2014;30:66-72.

15. Chong H, Li Q. Microbial production of rhamnolipids: opportunities, challenges and strategies. Microb Cell Fact. 2017:16:137.

16. Díaz De Rienzo MA, Kamalanathan ID, Martin PJ. Comparative study of the production of rhamnolipid biosurfactants by $B$. thailandensis E264 and P. aeruginosa ATCC 9027 using foam fractionation. Process Biochem. 2016:51:820-7.

17. Bahia FM, de Almeida GC, de Andrade LP, Campos CG, Queiroz LR, da Silva RLV, Abdelnur PV, Corrêa JR, Bettiga M, Parachin NS. Rhamnolipids production from sucrose by engineered Saccharomyces cerevisiae. Sci Rep. 2018:8:2905.

18. Tavares LFD, Silva PM, Junqueira M, Mariano DCO, Nogueira FCS, Domont GB, Freire DMG, Neves BC. Characterization of rhamnolipids produced by wild-type and engineered Burkholderia kururiensis. Appl Microbiol Biotechnol. 2013;97:1909-21.

19. Solaiman DKY, Ashby RD, Gunther NW, Zerkowski JA. Dirhamnose-lipid production by recombinant nonpathogenic bacterium Pseudomonas chlororaphis. Appl Microbiol Biotechnol. 2015;99:4333-42.

20. Han L, Liu P, Peng Y, Lin J, Wang Q, Ma Y. Engineering the biosynthesis of novel rhamnolipids in Escherichia coli for enhanced oil recovery. J Appl Microbiol. 2014;117:139-50.

21. Wang QH, Fang XD, Bai BJ, Liang XL, Shuler PJ, Goddard WA, Tang YC. Engineering bacteria for production of rhamnolipid as an agent for enhanced oil recovery. Biotechnol Bioeng. 2007;98:842-53.

22. Cabrera-Valladares N, Richardson AP, Olvera C, Trevino LG, Deziel E, Lepine F, Soberon-Chavez G. Monorhamnolipids and 3-(3-hydroxyalkanoyloxy)alkanoic acids (HAAs) production using Escherichia coli as a heterologous host. Appl Microbiol Biotechnol. 2006;73:187-94.

23. Wittgens A, Tiso T, Arndt TT, Wenk P, Hemmerich J, Muller C, Wichmann R, Kupper B, Zwick M, Wilhelm S, et al. Growth independent rhamnolipid production from glucose using the non-pathogenic Pseudomonas putida KT2440. Microb Cell Fact. 2011;10:80.

24. Ochsner UA, Reiser J, Fiechter A, Witholt B. Production of Pseudomonas aeruginosa rhamnolipid biosurfactants in heterologous hosts. Appl Environ Microbiol. 1995;61:3503-6.

25. Zhao F, Shi R, Zhao J, Li G, Bai X, Han S, Zhang Y. Heterologous production of Pseudomonas aeruginosa rhamnolipid under anaerobic conditions for microbial enhanced oil recovery. J Appl Microbiol. 2015;118:379-89.

26. Randhawa KKS, Rahman PK. Rhamnolipid biosurfactants-past, present and future scenario of global market. Front Microbiol. 2014;5:454.

27. Nitschke M, Sousa e Silva S. Recent food applications of microbial surfactants. Crit Rev Food Sci Nutr. 2018:58:631-8.

28. Abdel-Mawgoud AM, Lepine F, Deziel E. A stereospecific pathway diverts beta-oxidation intermediates to the biosynthesis of rhamnolipid biosurfactants. Chem Biol. 2014;21:156-64. 
29. Dobler L, Vilela LF, Almeida RV, Neves BC. Rhamnolipids in perspective: gene regulatory pathways, metabolic engineering, production and technological forecasting. New Biotechnol. 2016;33:123-35.

30. Ochsner UA, Fiechter A, Reiser J. Isolation, characterization, and expression in Escherichia coli of the Pseudomonas aeruginosa rhIAB genes encoding a rhamnosyltransferase involved in rhamnolipid biosurfactant synthesis. J Biol Chem. 1994;269:19787-95.

31. Soberon-Chavez G, Lepine F, Deziel E. Production of rhamnolipids by Pseudomonas aeruginosa. Appl Microbiol Biotechnol. 2005;68:718-25.

32. Olvera C, Goldberg JB, Sanchez R, Soberon-Chavez G. The Pseudomonas aeruginosa algC gene product participates in rhamnolipid biosynthesis. FEMS Microbiol Lett. 1999;179:85-90.

33. Déziel $E$, Lépine F, Milot $S$, Villemur R. rhlA is required for the production of a novel biosurfactant promoting swarming motility in Pseudomonas aeruginosa: 3-(3-hydroxyalkanoyloxy)alkanoic acids (HAAs), the precursors of rhamnolipids. Microbiology. 2003;149:2005-13.

34. Rahim R, Ochsner UA, Olvera C, Graninger M, Messner P, Lam JS, Soberon-Chavez G. Cloning and functional characterization of the Pseudomonas aeruginosa rhIC gene that encodes rhamnosyltransferase 2, an enzyme responsible for di-rhamnolipid biosynthesis. Mol Microbiol. 2001;40:708-18.

35. Dusane DH, Zinjarde SS, Venugopalan VP, McLean RJ, Weber MM, Rahman PK. Quorum sensing: implications on rhamnolipid biosurfactant production. Biotechnol Genet Eng Rev. 2010;27:159-84.

36. Wittigens A, Tiso T, Arndt TT, Wenk P, Hemmerich J, Muller C, Wichmann R, Kupper B, Zwick M, Wilhelm S, et al. Growth independent rhamnolipid production from glucose using the non-pathogenic Pseudomonas putida KT2440. Microbial Cell Fact. 2011;10:80.

37. Williams P, Camara M. Quorum sensing and environmental adaptation in Pseudomonas aeruginosa: a tale of regulatory networks and multifunctional signal molecules. Curr Opin Microbiol. 2009;12:182-91.

38. Ochsner UA, Hembach T, Fiechter A. Production of rhamnolipid biosurfactants. Adv Biochem Eng Biotechnol. 1996;53:89-118.

39. Ochsner UA, Koch AK, Fiechter A, Reiser J. Isolation and characterization of a regulatory gene affecting rhamnolipid biosurfactant synthesis in Pseudomonas aeruginosa. J Bacteriol. 1994;176:2044-54.

40. Ochsner UA, Reiser J. Autoinducer-mediated regulation of rhamnolipid biosurfactant synthesis in Pseudomonas aeruginosa. Proc Natl Acad Sci. 1995;92:6424-8.

41. Banat IM, Satpute SK, Cameotra SS, Patil R, Nyayanit NV. Cost effective technologies and renewable substrates for biosurfactants' production. Front Microbiol. 2014;5:697.

42. Reis RS, da Rocha SLG, Chapeaurouge DA, Domont GB, Santa Anna LMM, Freire DMG, Perales J. Effects of carbon and nitrogen sources on the proteome of Pseudomonas aeruginosa PA1 during rhamnolipid production. Process Biochem. 2010;45:1504-10.

43. Nitschke M, Costa SG, Contiero J. Structure and applications of a rhamnolipid surfactant produced in soybean oil waste. Appl Biochem Biotechnol. 2010;160:2066-74

44. Nitschke M, Costa SG, Haddad R, Goncalves LA, Eberlin MN, Contiero J. Oil wastes as unconventional substrates for rhamnolipid biosurfactant production by Pseudomonas aeruginosa LBI. Biotechnol Prog. 2005;21:1562-6.

45. Gunther NW, Nunez A, Fett W, Solaiman DK. Production of rhamnolipids by Pseudomonas chlororaphis, a nonpathogenic bacterium. Appl Environ Microbiol. 2005;71:2288-93.

46. Makkar R, Cameotra S. An update on the use of unconventional substrates for biosurfactant production and their new applications. Appl Microbiol Biotechnol. 2002;58:428-34.

47. Kaskatepe B, Yildiz S. Rhamnolipid Biosurfactants produced by pseudomonas species. Braz Arch Biol Technol. 2016;59:e16160786.

48. Sarachat T, Pornsunthorntawee $\mathrm{O}$, Chavadej S, Rujiravanit R. Purification and concentration of a rhamnolipid biosurfactant produced by Pseudomonas aeruginosa SP4 using foam fractionation. Bioresour Technol. 2010;101:324-30.

49. Rodrigues MS, Moreira FS, Cardoso VL, de Resende MM. Soy molasses as a fermentation substrate for the production of biosurfactant using Pseudomonas aeruginosa ATCC 10145. Environ Sci Pollut Res. 2017;24:18699-709.

50. Li A-h, Xu M-y, Sun W, Sun G-p. Rhamnolipid production by Pseudomonas aeruginosa GIM 32 using different substrates including molasses distillery wastewater. Appl Biochem Biotechnol. 2011;163:600-11.

51. Dubey K, Juwarkar A. Distillery and curd whey wastes as viable alternative sources for biosurfactant production. World J Microbiol Biotechnol. 2001;17:61-9.

52. Rahiman F, Pool EJ. The effect of sugar cane molasses on the immune and male reproductive systems using in vitro and in vivo methods. Iran J Basic Med Sci. 2016;19:1125-30.

53. Suryanti V, Marliyana SD, Wulandari A: Biosurfactant production by Pseudomonas fluorescens growing on molasses and its application in phenol degradation. In: International Conference of Chemical and Material Engineering (ICCME). American Institute of Physics; 2015: 1699, 040003-040001-040003-040006;:

54. Makkar RS, Cameotra SS. Utilization of molasses for biosurfactant production by two bacillus strains at thermophilic conditions. Short Commun. 1997;74:887-9.

55. Patel R, Desai A. Biosurfactant production by Pseudomonas aeruginosa GS3 from molasses. Lett Appl Microbiol. 1997;25:91-4.

56. Saimmai A, Sobhon V, Maneerat S. Molasses as a whole medium for biosurfactants production by bacillus strains and their application. Appl Biochem Biotechnol. 2011;165:315-35.

57. Dos Santos Lopes V, Fischer J, Pinheiro TMA, Cabral BV, Cardoso VL, Filho UC. Biosurfactant and ethanol co-production using Pseudomonas aeruginosa and Saccharomyces cerevisiae co-cultures and exploded sugarcane bagasse. Renew Energy. 2017;109:305-10.

58. Naspolini BF, De Oliveira Machado AC, Cravo Junior WB, Freire DMG, Cammarota MC. Bioconversion of sugarcane vinasse into highadded value products and energy. BioMed Res Int. 2017. https://doi. org/10.1155/2017/8986165.

59. Onbasli D, Aslim B. Biosurfactant production in sugar beet molasses by some Pseudomonas spp. J Environ Biol. 2009:30:161-3.

60. de Lima AM, de Souza RR. Use of sugar cane vinasse as substrate for biosurfactant production using Bacillus subtilis PC. Chem Eng Trans. 2014;37:673-8

61. Rodrigues Reis CE, Hu B. Vinasse from sugarcane ethanol production: better treatment or better utilization? Front Energy Res. 2017. https:// doi.org/10.3389/fenrg.2017.00007.

62. Naspolini BF, De Oliveira Machado AC, Cravo Junior WB, Freire DMG, Cammarota MC. Bioconversion of sugarcane vinasse into highadded value products and energy. BioMed Res Int. 2017. https://doi. org/10.1155/2017/8986165.

63. Azran M, Fazielawanie N, Saidin J, Wahid M, Bhubalan K. Bioconversion of cane sugar refinery by-products into rhamnolipid by marine Pseudomonas aeruginosa. In International Conference on Beneficial Microbes (ICOBM); Penang, Malaysia. 2014.

64. Li Q, Ng WT, Wu JC. Isolation, characterization and application of a cellulose-degrading strain Neurospora crassa S1 from oil palm empty fruit bunch. Microb Cell Fact. 2014;13:157.

65. Li Q, Ng WT, Puah SM, Bhaskar RV, Soh LS, MacBeath C, Parakattil P, Green P, Wu JC. Efficient production of fermentable sugars from oil palm empty fruit bunch by combined use of acid and whole cell culture-catalyzed hydrolyses. Biotechnol Appl Chem. 2014;61:426-31.

66. Bras JL, Cartmell A, Carvalho AL, Verze G, Bayer EA, Vazana Y, Correia MA, Prates JA, Ratnaparkhe S, Boraston AB, et al. Structural insights into a unique cellulase fold and mechanism of cellulose hydrolysis. Proc Natl Acad Sci USA. 2011;108:5237-42.

67. Chundawat SP, Beckham GT, Himmel ME, Dale BE. Deconstruction of lignocellulosic biomass to fuels and chemicals. Annu Rev Chem Biomol Eng. 2011;2:121-45.

68. Ruiz-Duenas FJ, Martinez AT. Microbial degradation of lignin: how a bulky recalcitrant polymer is efficiently recycled in nature and how we can take advantage of this. Microb Biotechnol. 2009;2:164-77.

69. Payasi A, Mishra NN, Chaves AL, Singh R. Biochemistry of fruit softening: an overview. Physiol Mol Biol Plants. 2009;15:103-13.

70. Baldrian P, Valaskova V. Degradation of cellulose by basidiomycetous fungi. FEMS Microbiol Rev. 2008;32:501-21.

71. Bayer EA, Lamed R, Himmel ME. The potential of cellulases and celIulosomes for cellulosic waste management. Curr Opin Biotechnol. 2007; 18:237-45. 
72. Kuhad RC, Singh A, Eriksson KE. Microorganisms and enzymes involved in the degradation of plant fiber cell walls. Adv Biochem Eng Biotechnol. 1997;57:45-125.

73. Kaskatepe B, Yildiz S, Gumustas M, Ozkan SA. Rhamnolipid Production by Pseudomonas putida IBS036 and Pseudomonas pachastrellae LOS20 with using pulps. Curr Pharm Anal. 2017;13:138-44.

74. Iroha OK, Njoku OU, Ogugua VN, Okpashi VE. Characterization of biosurfactant produced from submerged fermentation of fruits bagasse of yellow cashew (Anacardium occidentale) using Pseudomonas aeruginosa. Afr J Environ Sci Technol. 2015;9:473-81.

75. Rocha MV, Oliveira AH, Souza MC, Goncalves LR. Natural cashew apple juice as fermentation medium for biosurfactant production by Acinetobacter calcoaceticus. World J Microbiol Biotechnol. 2006;22:1295-9.

76. Ansari FA, Hussain S, Ahmed B, Akhter J, Shoeb E. Use of potato peel as cheap carbon source for the bacterial production of biosurfactants. Int J Biol Res. 2014;2:27-31.

77. George S, Jayachandran K. Analysis of rhamnolipid biosurfactants produced through submerged fermentation using orange fruit peelings as sole carbon source. Appl Biochem Biotechnol. 2009;158:694-705.

78. Dubey KV, Charde PN, Meshram SU, Yadav SK, Singh S, Juwarkar AA. Potential of new microbial isolates for biosurfactant production using combinations of distillery waste with other industrial wastes. Pet Environ Biotechnol. 2012;12:1-11.

79. Vecino X, Rodriguez-Lopez L, Gudina E, Cruz J, Moldes A, Rodrigues L. Vineyard pruning waste as an alternative carbon source to produce novel biosurfactants by Lactobacillus paracasei. J Ind Eng Chem. 2017;55:40-9.

80. Portilla-Riveria O, Torrado A, Dominguez J, Moldes A. Stability and emulsifying capacity of biosurfactants obtained from lignocellulosic sources using Lactobacillus pentosus. J Agric Food Chem. 2008;56:8074-80.

81. Jamal P, Mir S, Alam MZ, Wan Nawawi WMF. Isolation and selection of new biosurfactant-producing bacteria from degraded palm kernel cake under liquid state fermentation. J Oleo Sci. 2014;63:795-804.

82. Noparat P, Maneerat S, Saimmai A. Utilization of palm oil decanter cake as a novel substrate for biosurfactant production from a new and promising strain of Ochrobactrum anthropi 2/3. World J Microbiol Biotechnol. 2014:30:865-77.

83. Abas MR, Abdul Kader AJ, Khalil MS, Abdul Hamid A, Mohd Isa MH. Production of surfactin from Bacillus subtilis ATCC 21332 by using treated palm oil mill effluent (POME) as fermentation media. In International conference on food and agricultural sciences; Singapore. IACSIT Press; 2013: IPCBEE vol. 55.

84. Chooklin CS, Phertmean S, Cheirsilp B, Maneerat S, Saimmai A. Utilization of palm oil mill effluent as a novel and promising substrate for biosurfactant production by Nevskia ramosa NA3. Songklanakarin J Sci Technol. 2013;35:167-76.

85. Kosugi A, Tanaka R, Magara K, Murata Y, Arai T, Sulaiman O, Hashim R, Abdul Hamid ZA, Azri Yahya MK, Mohd Yusof MN, et al. Ethanol and lactic acid production using sap squeezed from old oil palm trunks felled for replanting. J Biosci Bioeng. 2010;110:322-5.

86. Mohd Zahari MAK, Zakaria MR, Ariffin H, Mokhtar MN, Salihon J, Shirai Y, Hassan MA. Renewable sugars from oil palm frond juice as an alternative novel fermentation feedstock for value-added products. Biores Technol. 2012;110:566-71.

87. Komonkiat I, Cheirsilp B. Felled oil palm trunk as a renewable source for biobutanol production by Clostridium spp. Biores Technol. 2013;146:200-7.

88. Sidkey N, Mohamed H, Elkhouly H. Evaluation of different screening methods for biosurfactant producers isolated from contaminated Egyptian samples grown on industrial olive oil processing waste. $\mathrm{Br}$ Microbiol Res J. 2016:17:1-19.

89. Ramirez IM, Vaz DA, Banat IM, Marchant R, Alameda EJ, Roman MG. Hydrolysis of olive mill waste to enhance rhamnolipids and surfactin production. Biores Technol. 2016;205:1-6.

90. Mercade M, Manresa M, Robert M, Espuny M, De Andres C, Guinea J. Olive oil mill effluent (OOME): new substrate for biosurfactant production. Biores Technol. 1993;43:1-6.

91. Gudina EJ, Rodrigues Al, de Freitas V, Azevedo Z, Teixeira JA, Rodrigues LR. Valorization of agro-industrial wastes towards the production of rhamnolipids. Biores Technol. 2016;212:144-50.
92. Ramirez IM, Tsaousi K, Rudden M, Marchant R, Alameda EJ, Roman MG, Banat IM. Rhamnolipid and surfactin production from olive oil mill waste as sole carbon source. Biores Technol. 2015;198:231-6.

93. Samykannu M, Achary A. Utilization of agro-industry residue for rhamnolipid production by P. aeruginosa AMB AS7 and its application in chromium removal. Appl Biochem Biotechnol. 2017;183:70-90.

94. Moldes AB, Torrado AM, Barral MT, Domínguez JM. Evaluation of biosurfactant production from various agricultural residues by Lactobacillus pentosus. J Agric Food Chem. 2007;55:4481-6.

95. Bustos G, De la Torre N, Moldes A, Cruz J, Dominguez J. Revalorization of hemicellulosic trimming vine shoots hydrolyzates trough continuous production of lactic acid and biosurfactants by L. pentosus. J Food Eng. 2007:78:405-12.

96. da Silva MET, Nascimento CC, Junior SD, Albuquerque PM. Biosurfactant production by Myrciaguianensis endophytic fungi. BMC Proc. 2014:8:P213.

97. Chooklin CS, Petmeaun S, Maneerat S, Saimmai A. Isolation and characterization of a biosurfactant from Deinococcus caeni PO5 using jackfruit seed powder as a substrate. Ann Microbiol. 2014;64:1007-20.

98. Patowary R, Patowary K, Kalita MC, Deka S. Utilization of paneer whey waste for cost-effective production of rhamnolipid biosurfactant. Appl Biochem Biotechnol. 2016;180:383-99.

99. Colak AK, Kahraman $\mathrm{H}$. The use of raw cheese whey and olive oil mill wastewater for rhamnolipid production by recombinant Pseudomonas aeruginosa. Environ Exp Biol. 2013;11:125-30.

100. Rodrigues L, Moldes A, Teixeira J, Oliveira R. Kinetic study of fermentative biosurfactant production by Lactobacillus strains. Biochem Eng J. 2006;28:109-16.

101. Yilmaz F, Ergene A, Yalcin E, Tan S. Production and characterization of biosurfactants produced by microorganisms isolated from milk factory wastewaters. Environ Technol. 2009:30:1397-404.

102. Suryanti V, Handayani D, Marliyana S, Suratmi S. Physicochemical properties of biosurfactant produced by Pseudomonas fluorescens grown on Whey Tofu. In International conference on advanced materials for better future. IOP Conf. Series: Materials Science and Engineering; 2016: 176, 012003.

103. Suryanti V, Marliyana SD, Handayani DS, Ratnaningrum D. Production and characterization of biosurfactant by Pseudomonas fluorescens using cassava flour wastewater as media. Indo J Chem. 2013;13:229-35.

104. Costa SG, Lepine F, Milot S, Deziel E, Nitschke M, Contiero J. Cassava wastewater as a substrate for the simultaneous production of rhamnolipids and polyhydroxyalkanoates by Pseudomonas aeruginosa. J Ind Microbiol Biotechnol. 2009;36:1063-72.

105. Fai AEC, Simiqueli APR, De Andrade CJ, Ghiselli G, Pastore GM. Optimized production of biosurfactant from Pseudozyma tsukubaensis using cassava wastewater and consecutive production of galactooligosaccharides: an integrated process. Biocatal Agric Biotechnol. 2015;4:535-42.

106. Varjani SJ, Upasani VN. Critical review on biosurfactant analysis, purification and characterization using rhamnolipid as a model biosurfactant. Biores Technol. 2017;232:389-97.

107. Nicolo MS, Cambria MG, Impallomeni G, Rizzo MG, Pellicorio C, Ballistreri A, Guglielmino SP. Carbon source effects on the mono/dirhamnolipid ratio produced by Pseudomonas aeruginosa L05, a new human respiratory isolate. New Biotechnol. 2017;39:36-41.

108. Sarachat T, Pornsunthorntawee O, Chavadej S, Rujiravanit R. Purification and concentration of a rhamnolipid biosurfactant produced by Pseudomonas aeruginosa SP4 using foam fractionation. Biores Technol. 2010;101:324-30.

109. Shah MUH, Sivapragasam M, Moniruzzaman M, Yusup SB. A comparison of recovery methods of rhamnolipids produced by Pseudomonas aeruginosa. Proc Eng. 2016;148:494-500.

110. Santos DKF, Rufino RD, Luna JM, Santos VA, Sarubbo LA. Biosurfactants: multifunctional biomolecules of the 21st century. Int J Mol Sci. 2016;17:401.

111. Cirstea DM, Stefanescu M, Pahontu JM, Cornea CP. Use of some carbon sources by Pseudomonas strains for synthesizing polyhydroxyalkanoates and/or rhamnolipids. Romanian Biotechnol Lett. 2014;19:9400-8.

112. Mata-Sandoval JC, Karns J, Torrents A. Effect of nutritional and environmental conditions on the production and composition of rhamnolipids by P. aeruginosa UG2. Microbiol Res. 2001;155:249-56. 
113. Zodpe S. Rhamnolipid biosurfactant production by strain of Pseudomonas aeruginosa using different raw materials. Int J Curr Microbiol Appl Sci. 2016;5:407-13.

114. Abouseouda M, Maachi R, Amrane A, Boudergua S, Nabi A. Evaluation of different carbon and nitrogen sources in production of biosurfactant by Pseudomonas fluorescens. Desalination. 2008;223:143-51.

115. Muller MM, Hormann B, Kugel M, Syldatk C, Hausmann R. Evaluation of rhamnolipid production capacity of Pseudomonas aeruginosa PAO1 in comparison to the rhamnolipid over-producer strains DSM 7108 and DSM 2874. Appl Microbiol Biotechnol. 2011;89:585-92.

116. Ndlovu T, Rautenbach M, Khan S, Khan W. Variants of lipopeptides and glycolipids produced by Bacillus amyloliquefaciens and Pseudomonas aeruginosa cultured in different carbon substrates. AMB Express. 2017:7:109.

117. Parhi P, Jadhav W, Bhadekar R. Increase in production of biosurfactant from Oceanobacillus sp. BRI 10 using low cost substrates. Songklanakarin J Sci Technol. 2016;38:207-11

118. Jain RM, Mody K, Joshi N, Mishra A, Jha B. Effect of unconventional carbon sources on biosurfactant production and its application in bioremediation. Int J Biol Macromol. 2013:62:52-8.

119. Samad A, Zhang J, Chen D, Liang Y. Sophorolipid production from biomass hydrolysates. Appl Biochem Biotechnol. 2015;175:2246-57.

120. Daverey A, Pakshirajan K. Production of sophorolipids by the yeast Candida bombicola using simple and low cost fermentative media. Food Res Int. 2009:42:499-504.

121. Zhang L, Pemberton JE, Maier RM. Effect of fatty acid substrate chain length on Pseudomonas aeruginosa ATCC 9027 monorhamnolipid yield and congener distribution. Process Biochem. 2014;49:989-95.

122. Zhang $Y H$, Lynd LR. Toward an aggregated understanding of enzymatic hydrolysis of cellulose: noncomplexed cellulase systems. Biotechnol Bioeng. 2004;88:797-824.

123. Tu M, Chandra RP, Saddler JN. Evaluating the distribution of cellulases and the recycling of free cellulases during the hydrolysis of lignocellulosic substrates. Biotechnol Prog. 2007;23:398-406.

124. Feng $Y$, Jiang J, Zhu L, Yue L, Zhang J, Han S. Effects of tea saponin on glucan conversion and bonding behaviour of cellulolytic enzymes during enzymatic hydrolysis of corncob residue with high lignin content. Biotechnol Biofuels. 2013;6:161.

125. Zhang Q, He G, Wang J, Cai W, Xu Y. Two-stage co-hydrolysis of rice straw by Trichoderma reesei ZM4-F3 and Pseudomonas aeruginosa BSZ07. Biomass Bioenerg. 2009;33:1464-8.

126. Menegol D, Scholl AL, Fontana RC, Dillon AJP, Camassola M. Increased release of fermentable sugars from elephant grass by enzymatic hydrolysis in the presence of surfactants. Energy Convers Manag. 2014;88:1252-6.

127. Grosso-Becerra MV, Gonzalez-Valdez A, Granados-Martinez MJ, Morales E, Servin-Gonzalez L, Mendez JL, Delgado G, Morales-Espinosa R, Ponce-Soto GY, Cocotl-Yanez M, Soberon-Chavez G. Pseudomonas aeruginosa ATCC 9027 is a non-virulent strain suitable for mono-rhamnolipids production. Appl Microbiol Biotechnol. 2016;100:9995-10004.

128. Onwosi CO, Odibo FJC. Effects of carbon and nitrogen sources on rhamnolipid biosurfactant production by Pseudomonas nitroreducens isolated from soil. World J Microbiol Biotechnol. 2012·28:937-42.

129. Janek T, Łukaszewicz M, Krasowska A. Identification and characterization of biosurfactants produced by the Arctic bacterium Pseudomonas putida BD2. Colloids Surf B. 2013;110:379-86

130. Mizrachi E, Mansfield SD, Myburg AA. Cellulose factories: advancing bioenergy production from forest trees. New Phytol. 2012;194:54-62.

131. Chauvigne-Hines LM, Anderson LN, Weaver HM, Brown JN, Koech PK, Nicora CD, Hofstad BA, Smith RD, Wilkins MJ, Callister SJ, Wright AT. Suite of activity-based probes for cellulose-degrading enzymes. J Am Chem Soc. 2012:134:20521-32
132. Bayer EA, Belaich JP, Shoham Y, Lamed R. The cellulosomes: multienzyme machines for degradation of plant cell wall polysaccharides. Annu Rev Microbiol. 2004:58:521-54.

133. De Araujo CKC, De Oliveria Campos A, De Arajuo Padilha CE, De Sousa Junior FC, Do Nascimento RJA, De Macedo GR, Dos Santos ES. Enhancing enzymatic hydrolysis of coconut husk through Pseudomonas aeruginosa AP 029/GLVIIA rhamnolipid preparation. Biores Technol. 2017;237:20-6.

134. Moxley G, Zhu Z, Zhang YH. Efficient sugar release by the cellulose solvent-based lignocellulose fractionation technology and enzymatic cellulose hydrolysis. J Agric Food Chem. 2008;56:7885-90.

135. Jacobsen SE, Wyman CE. Cellulose and hemicellulose hydrolysis models for application to current and novel pretreatment processes. Appl Biochem Biotechnol. 2000;84-86:81-96.

136. Duguid KB, Montross MD, Radtke CW, Crofcheck CL, Wendt LM, Shearer SA. Effect of anatomical fractionation on the enzymatic hydrolysis of acid and alkaline pretreated corn stover. Bioresour Technol. 2009:100:5189-95.

137. Waghmode S, Kulkarni C, Shukla S, Sursawant P, Velhal C. Low cost production of biosurfactant from different substrates and their comparative study with commercially available chemical surfactant. Int J Sci Technol Res. 2014;3:146-9.

138. Marti ME, Colonna WJ, Reznik G, Pynn M, Jarrell K, Lamsal B, Glatz CE. Production of fatty-acyl-glutamate biosurfactant by Bacillus subtilis on soybean co-products. Biochem Eng J. 2015;95:48-55.

139. Zhu Z, Zhang F, Wei Z, Ran W, Shen Q. The usage of rice straw as a major substrate for the production of surfactin by Bacillus amyloliquefaciens XZ-173 in solid-state fermentation. J Environ Manag. 2013;127:96-102.

140. Zhu Z, Zhang G, Luo Y, Ran W, Shen Q. Production of lipopeptides by Bacillus amyloliquefaciens XZ-173 in solid state fermentation using soybean flour and rice straw as the substrate. Biores Technol. 2012;112:254-60

141. Konishi M, Yoshida Y, Horiuchi J-i. Efficient production of sophorolipids by Starmerella bombicola using a corncob hydrolysate medium. J Biosci Bioeng. 2015;119:317-22

142. Chen C, Lin J, Wang W, Huang H, Li S: Cost-effective production of surfactin from xylose-rich corncob hydrolysate using Bacillus subtilis BS-37. Waste Biomass Valor 2017.

143. Zhi Y, Wu Q, Xu Y. Production of surfactin from waste distillers' grains by co-culture fermentation of two Bacillus amyloliquefaciens strains. Biores Technol. 2017;235:96-103.

144. Joshi S, Bharucha C, Jha S, Yadav S, Nerurkar A, Desai AJ. Biosurfactant production using molasses and whey under thermophilic conditions. Biores Technol. 2008;99:195-9.

145. Al-Wahaibi Y, Joshi S, Al-Bahry S, Elshafie A, Al-Bemani A, Shibulal B. Biosurfactant production by Bacillus subtilis B30 and its application in enhancing oil recovery. Colloids Surf B. 2014;114:324-33.

146. Gurjar J, Sengupta B. Production of surfactin from rice mill polishing residue by submerged fermentation using Bacillus subtilis MTCC 2423. Biores Technol. 2015;189:243-9.

147. Slivinski CT, Mallmann E, De Araujo JM, Mitchell DA, Krieger N. Production of surfactin by Bacillus pumilus UFPEDA 448 in solid-state fermentation using a medium based on okara with sugarcane bagasse as a bulking agent. Process Biochem. 2012;47:1848-55.

148. Velioglu Z, Urek RO. Optimization of cultural conditions for biosurfactant production by Pleurotus djamor in solid state fermentation. $J$ Biosci Bioeng. 2015;120:526-31.

149. Rahim R, Burrows LL, Monteiro MA, Perry MB, Lam JS. Involvement of the $\mathrm{rml}$ locus in core oligosaccharide and $O$ polysaccharide assembly in Pseudomonas aeruginosa. Microbiology. 2000;146:2803-14. 